\title{
QUANTITATIVE ANALYSIS OF BIOACTIVE COMPOUNDS OF ARTEMISIA NILAGIRICA (CLARKE) PAMP. LEAF EXTRACT
}

\author{
PARAMESWARI PRADEEP ${ }^{1 *}$, DEVIKA RENGASWAMY²
}

${ }^{1}$ Department of Biotechnology, Sathyabama University, Chennai - 600 119, Tamil Nadu, India. ${ }^{2}$ Department of Biotechnology, Aarupadai Veedu Institute of Technology, Chennai - 603 104, Tamil Nadu, India. Email: eshwari_2007@yahoo.com

Received: 14 June 2016, Revised and Accepted: 27 June 2016

\section{ABSTRACT}

Objective: The points of this exploration work were to decide the quantitative examination of bioactive mixes. Customarily, cutting edge meds rely on the phytochemicals got from the plant source in bigger extents. Numerous bioactive auxiliary metabolites have a positive metabolic reaction on different human diseases.

Methods: In the present examination, Artemisia nilagirica, leaves were gathered, dried, powdered and put away in hermetically sealed compartments for quantitative investigation of phytochemicals according to standard strategies.

Results: The methanolic leaf concentrate of enrolled $4.33 \mathrm{mg}$ of alkaloids, $1.22 \mathrm{mg}$ of saponins, $12.4 \mathrm{mg}$ of tannins, $24.3 \mathrm{mg}$ of glycosides, $10.2 \mathrm{mg}$ terpenoids, $1.33 \mathrm{mg}$ of coumarin, $59.4 \mathrm{mg}$ of amino acids, $12.2 \mathrm{mg}$ of fatty acids, $17.2 \mathrm{mg}$ of flavonoids, $10.2 \mathrm{mg}$ of phenols, and steroids in follows separately.

Conclusion: The plant has a high helpful quality as far as an assortment of phytochemicals from leaf remove and had let to a sure level toward extraction and refinement of specific bioactive mixes for human nourishment.

Keywords: Artemisia nilagirica, Secondary metabolites, Quantitative analysis, Leaf extract, Flavonoids.

(C) 2016 The Authors. Published by Innovare Academic Sciences Pvt Ltd. This is an open access article under the CC BY license (http://creativecommons. org/licenses/by/4. 0/) DOI: http://dx.doi.org/10.22159/ajpcr.2016.v9s2.13480

\section{INTRODUCTION}

The World Health Organization uncovered that $80 \%$ of world population relies on plant metabolites for their restorative worth in different wellbeing parts [1]. Different examinations on metabolites from plant sources brought about potential medications by mixes and taken an exponential development as far as common root and lesser reactions [2-4]. Tagetes erecta Linn. (Marigold) phytoconstituents are accounted for to be very powerful against kidney inconveniences, solid agony, ulcers and wounds [5] and stomach ulcer, diabetes and fever expand lactation in moms, spennatorrhea [6]. Gymnem asylvestere has been turned out to be very powerful hostile to diabetic, mitigating, against microbial, hepatoprotective, and against hyperlipidemic plants [7,8]. Napoleonaimperialis a woody plant is utilized as pain relieving, tonic, antitussive, antiasthmatic, etc. [9]. It is to some degree dissolvable in water and is weakly key (pKa3.5) in nature. Post oral association, it is immediately acclimatized from gastrointestinal tract and has a level out bioavailability of around $60 \%$ in individuals [10]. Recent research demonstrate that the flavonoids (bioactive auxiliary metabolite) are very compelling cancer prevention agents [11] with lower danger than butylated hydroxyanisole and butylated hydroxytoluene (manufactured antioxidants), and they are known as "response modifier" [12], mitigating [13], hostile to microbial [14,15]. Carthamus tinctorius bloom (carthamin) is powerful on circulatory framework related sicknesses [16], purgative [17], swelling connected with injury, unending and atrophic gastritis [18], gynecological ailment [19], and for the treatment of cardiomyopathy [20]. The present examination is expected to measure the phytochemicals of Artemisia nilagirica (Clarke) Pamp.

\section{METHODS}

A. nilagirica (Clarke) Pamp. leaves were gathered, isolated (new and solid), air-dried, powdered and put away in a sealed shut holder for quantitative examination of bioactive mixes. The dried powdered leaf tests were subjected to different estimations, for example, alkaloids, saponins, tannins, glycosides, terpenoids, coumarin, amino acids, fatty acids, flavonoids, phenols, and steroids according to standard techniques [21] (Table 1).

\section{RESULTS}

In the earlier study [22], the phytochemicals of the A. nilagirica (Clarke) Pamp was subjected to subjective studies and the present examination was centered around the quantitative examination of the enrolled phytochemicals. The methanolic leaf hoard of chose in the most dumbfounding measure of move in glycosides and flavonoids and minimum yield are accessible in amino acids. The leaf concentrate was subjected to quantitative estimation, and the result is ordered.

\section{DISCUSSION}

In this study, alkaloid focus in the leaf concentrate of $4.33 \mathrm{mg}$ which was demonstrated by the nearness of ruddy cocoa shading [23] and they are effective as cell reinforcements, antibacterial, antifungal, and antiviral [24]. The alkaloids are utilized as solutions (e.g.) cymaline as antiarrhythmic vincamine as antitumor, cocaine as sedative medications [25]. It has been accounted for that alkaloids secluded from the bases of Polyalthia longifolia var. pendula indicated antimicrobial action [26]. Terpenes are substantial and shifted class of natural mixes which incorporates every one of the assortments saps, and they frame the vital oils and utilized as normal added substances for nourishment $[27,28]$. The other essential auxiliary metabolites are coumarine (1.33 $\mathrm{mg}$ ) and has ended up being exceptionally powerful nutraceutical [29] and the leaf concentrate of T. erecta Linn. enlisted $2.55 \mathrm{mg}[25]$.

As like liquor, phenolic mixes have novel properties and are far-reaching among the plant kingdom and key for self-guarding from pathogen [27]. The plant has proficiency against microbial development and the subjective phytochemical screening additionally uncovered that the plant is rich wellspring of auxiliary metabolites [30]. Amid the most 
Table 1: Quantification of secondary metabolites

\begin{tabular}{lll}
\hline S. No. & Phytochemicals & Amount/g of extract \\
\hline 1. & Alkaloid & $4.33 \mathrm{mg}$ \\
2. & Saponins & $1.22 \mathrm{mg}$ \\
3. & Tannins & $12.4 \mathrm{mg}$ \\
4. & Glycosoids & $24.3 \mathrm{mg}$ \\
5. & Terpenoids & $10.2 \mathrm{mg}$ \\
6. & Coumarin & $1.33 \mathrm{mg}$ \\
7. & Amino acids & $1.33 \mathrm{mg}$ \\
8. & Fatty acids & $12.2 \mathrm{mg}$ \\
9. & Flavonoids & $17.2 \mathrm{mg}$ \\
10 & Phenols & $10.2 \mathrm{mg}$ \\
11. & Steroids & In traces \\
\hline
\end{tabular}

recent three decades, the plant-based phenolic mixes (e.g. berry tea, bean) were utilized as a part of medication plan for stroke, diabetes, Alzheimer's infection and so forth [31]. The aggregate flavonoids were higher in the blossom than leaf remove in T. erecta Linn. [32] at various focuses. The present day approved doctors demonstrated that the flavonoids are proficient in curing numerous infections and have change the metabolic boost through neurotransmitters [33], and they are exceedingly cell reinforcement operator [34] and expand the intracellular level of vitamin [35].

\section{CONCLUSION}

This study with A. nilagirica (Clarke) Pamp uncovered that the plant has a high helpful quality as far as an assortment of phytochemicals from leaf remove and had let to a sure level toward extraction and filtration of specific bioactive mixes for human aliment.

\section{REFERENCES}

1. Prianka D, Shalini T, Navneet VK. A brief study on marigold (Tagetes species). A review Int Pharm 2013;4(1):43-8.

2. Vijay KP, Laxman BC, Rajashri S, Nikam B, Yuvraj R, Janardhan PM. Pharmacognostic, physicochemical and phytochemical investigation of Tagetes erecta Linn. J Bio Sci Opnion 2003;1(1):21-4.

3. Erdogrul OT. Antibacterial activities of some plant extracts used in folk medicine. Pharm Biol 2002;40(4):269-73.

4. Gutierrez RH, Luba HH, Garrido SH. Antioxidant activity of Tagetes erecta essential oil. Antioxidant activity of Tagetes erecta essential oil. J Chil Chem Soc 2006;51(2):883-6.

5. Opara IC. A preliminary investigation in to the antiemetric properties of the leaf extract of Ocimum gratissimum. Phytother Res 1999;22:1692-4.

6. Nagat M, Baska E, Lawrence R, Saani M. Phytochemical screening, antioxidant and antibacterial activity of active compounds from Hemidermus indicus. Int J Curr Pharm Res 2016;8(2):24-7.

7. Odo GN. A preliminary pharmacological investigation in to the antispasmodic properties of the aqueous root extract of Napoleona imperialis A.B. Pharm Res 1984;3(4):838-42.

8. Bashir S, Gilani AH. Studies on the antioxidant and analgesic activities of Aztec marigold (Tagetes erecta) flowers. Phytother Res 2008;22(12):1692-4.

9. Raja RV, Ramanathan T, Savitha V. Studies on wound healing property of coastal. Med Plants 2009;1(1):39-44.

10. Raju KN, Sunitha T, Babu IS. Quantitative estimation of riluzole using solubilizing agent by UV-spectrophometry. Int J Appl Pharm 2014;6(3):4-5.

11. Pekkarine SS, Heinonen IM, Hopia AI. Flavonoids querocetin, myricetin, kaemferol and $(+)$ catechin as antioxidants in methyl linoleate. J Sci Food Agric 1999;79(4):499-506.

12. Cushnie TP, Lamb AJ. Antimicrobial activity of flavonoids. Int J
Antimicrob Agents 2005;26(5):343-56.

13. Cushnie TP, Lamb AJ. Recent advances in understanding the antibacterial properties of flavonoids. Int $\mathrm{J}$ Antimicrob Agents 2011;38(2):99-107.

14. de Sousa RR, Queiroz KC, Souza AC, Gurgueira SA, Augusto AC, Miranda MA, et al. Phosphoprotein levels, MAPK activities and NFkappaB expression are affected by fisetin. J Enzyme Inhib Med Chem 2007;22(4):439-44

15. Galedti F, Baarile E, Curir P, Dolei M, Lanzotti V. Flavonoids from carnation (Dianthus caryophyllus)and their antifungal activity. Phytochem Lett 2008;1(1):44-8.

16. Kazuma K, Takahashi T, Sato K, Takeuchi H, Matsumoto T, Okuno T. Quinochalcones and flavonoids from fresh florets in different cultivars of Carthamus tinctorius L. Biosci Biotechnol Biochem 2000;64(8):1588-99.

17. Kizil S, Cakmak O, Kirici S, Inan M. A comprehensive study on safflower (Carthamus tinctorius L.) in semi-arid condition. Biotechnol Biotechnol Equip 2008;40:947-53.

18. Lee YS, Choi CW, Kim JJ, Ganapathi A, Udayakumar R, Kim SC. Determination of mineral content in methanolic safflower (Carthamus tinctorius L.) Seed extract and its effect on osteoblast markers. Int J Mol Sci 2009;10(1):292-305.

19. Weber LW, Boll M, Stampfl A. Hepatotoxicity and mechanism of action of haloalkanes: Carbon tetrachloride as a toxicological model. Crit Rev Toxicol 2003;33(2):105-36.

20. Jun MS, Ha YM, Kim HS, Jang HJ, Kim YM, Lee YS, et al. Antiinflammatory action of methanol extract of Carthamus tinctorius involves in heme oxygenase-1 induction. $\mathrm{J}$ Ethnopharmacol 2011;133(2):524-30.

21. Giancaspro GI. Dietary supplements. Bot Pharm Forum 2013;27(2):2255-8

22. Parameswari P, Devika R. Qualitative screening of bioactive compounds of Artemisia nilagirica (Clarke) Pamp. Biotechnology - Present and future for sustainable healthcare development. J Chem Pharma Sci 2014;7(4):351-3.

23. Tariq AL, Reyaz AL. Quantitative phytochemical analysis of traditionally used medicinal plant Terminalia chebula. Int Res J Biotechnol 2013;4(5):101-5.

24. Singh R, Jasrai YT. Mumosa hamate (wild) a plant with antipathogenic properties. Int J Med Aromat-Plants 2012;2:677-83.

25. Devika R, Koilpillai J. An overview on plant secondary metabolites: Its medicinal importance. J Pharm Res 2012;5(2):984-6.

26. Kavita SM, Rasika CT, Swati D, Nirmala RD, Rajashree VK. Preliminary phytochemical analysis of Polyalthia longifolia seeds. Int J Pharm Pharm Sci 2012;4(1):450-1.

27. Devika R, Koilpillai J. Quantitative analysis of bioactive compounds from Tagetes erecta (Linn). Asian J Pharm Clin Res 2015;8(6):185-7.

28. Winkel-Shirley B. Flavonoid biosynthesis. A colorful model for genetics, biochemistry, cell biology, and biotechnology. Plant Physiol 2001;126(2):485-93.

29. Di Carlo G, Mascolo N, Izzo AA, Capasso F. Flavonoids: Old and new aspects of a class of natural therapeutic drugs. Life Sci 1999;65(4):337-53.

30. Rao ML, Savithramma N. Quantification of primary and secondary metabolites of Svensonia hyderobadensis - A rare medicinal plant. Int J Pharm Pharm Sci 2012;4(1):519-21.

31. Aqil F, Ahmad I, Mehmood Z. Antioxidant and free radical scavenging properties of twelve traditionally used Indian medicinal plants. Turk J Biol 2006;30:177-83.

32. Devika R, Koilpillai J. In vitro quantification study of flavonoids from Tagetes erecta. Asian J Biotechnol 2013;2(1):1-4.

33. Havsteen BH. The biochemistry and medical significance of the flavonoids. Pharmacol Ther 2002;96(2-3):67-202.

34. Miller JM, Bohmt BA. Flavonal and dihydroflavonal glycosides of Echinocereus triglochidiatus var. Gueneyi. Phytochemistry 1982;21(4):951-2.

35. Spedding G, Ratty A, Middleton E Jr. Inhibition of reverse transcriptases by flavonoids. Antiviral Res 1989;12(2):99-110. 